\title{
Concurrence of overt Cushing's syndrome and primary aldosteronism accompanied by aldosterone-producing cell cluster in adjacent adrenal cortex: case report
}

Yoshiro Fushimi, Fuminori Tatsumi, Junpei Sanada, Masashi Shimoda, Shinji Kamei, Shuhei Nakanishi, Kohei Kaku, Tomoatsu Mune and Hideaki Kaneto* (D)

\begin{abstract}
Background: Various adrenal disorders including primary aldosteronism and Cushing's syndrome lead to the cause of hypertension. Although primary aldosteronism is sometimes complicated with preclinical Cushing's syndrome, concurrence of overt Cushing's syndrome and primary aldosteronism is very rare. In addition, it has been drawing attention recently that primary aldosteronism is brought about by the presence of aldosterone-producing cell cluster in adjacent adrenal cortex rather than the presence of aldosterone-producing adenoma.

Case presentation: A 67-year-old Japanese female was referred to our institution due to moon face and central obesity. Based on various clinical findings and data, we diagnosed this subject as overt Cushing's syndrome and primary aldosteronism. Furthermore, in immunostaining for cytochrome P450 (CYP) 11B1, a cortisol-producing enzyme, diffuse staining was observed in tumorous lesion. Also, in immunostaining for CYP11B2, an aldosteroneproducing enzyme, CYP11B2 expression was not observed in tumorous lesion, but strong CYP11B2 expression was observed in adjacent adrenal cortex, indicating the presence of aldosterone-producing cell cluster.

Conclusions: We should bear in mind the possibility that concurrence of overt Cushing's syndrome and primary aldosteronism is accompanied by aldosterone-producing cell cluster in adjacent adrenal cortex.
\end{abstract}

Keywords: Overt Cushing's syndrome, Primary aldosteronism, Aldosterone-producing cell cluster, Cytochrome P450 11B1, Cytochrome P450 11B2

\footnotetext{
* Correspondence: kaneto@med.kawasaki-m.ac.jp

Department of Diabetes, Endocrinology and Metabolism, Kawasaki Medical

School, 577 Matsushima, Kurashiki 701-0192, Japan
}

C C The Author(s). 2021 Open Access This article is licensed under a Creative Commons Attribution 4.0 International License, which permits use, sharing, adaptation, distribution and reproduction in any medium or format, as long as you give appropriate credit to the original author(s) and the source, provide a link to the Creative Commons licence, and indicate if changes were made. The images or other third party material in this article are included in the article's Creative Commons licence, unless indicated otherwise in a credit line to the material. If material is not included in the article's Creative Commons licence and your intended use is not permitted by statutory regulation or exceeds the permitted use, you will need to obtain permission directly from the copyright holder. To view a copy of this licence, visit http://creativecommons.org/licenses/by/4.0/. The Creative Commons Public Domain Dedication waiver (http://creativecommons.org/publicdomain/zero/1.0/) applies to the data made available in this article, unless otherwise stated in a credit line to the data. 


\section{Background}

It is well known that primary aldosteronism is one of main causes of secondary hypertension. Patients with primary aldosternism more frequently bring about cardiovascular complication compared to those with essential hypertension [1]. However, this is relatively common and curable disease with appropriate diagnosis and treatment. In addion, it was thought that primary aldosteronism was brought about by aldosterone-producing adenoma [2-4]. However, it has been demonstrated recently that primary aldosteronism is closely associated with the presence of aldosterone-producing cell cluster in adjacent adrenal cortex [5-10]. Cushing's syndrome is another adrenal disorder which autonomously secretes large amounts of cortisol and leads to seconderly hypertension and/or diabetes mellitus. There are two types in this syndrome: preclinical Cushing's syndrome and overt Cushing's syndrome accompanied by several characteristic symptoms.

There have been several reports about complication of preclinical Cushing's syndrome and primary aldosteronism [2-4], but concurrence of overt Cushing's syndrome and primary aldosteronism is very rare. In addition, it was thought that both aldosterone and cortisol were produced in aldosterone-producing adenoma in subjects with preclinical Cushing's syndrome and primary aldosteronism [2-4].

Here we show a subject who had overt Cushing's syndrome and primary aldosteronism. Furthermore, in this subject, we detected cortisol-producing tumor and aldosterone-producing cell cluster in adjacent adrenal cortex, but not in the tumorous lesion, at the same time.

\section{Case presentation}

A 67-year-old Japanese female was referred to our institution due to moon face and central obesity. We thought that she had Cushing's syndrome from her appearance and measured various markers of the adrenal gland. The results were as follows: adrenocorticotropic hormone $(\mathrm{ACTH}),<1.0 \mathrm{pg} / \mathrm{mL}$; cortisol, $11.5 \mu \mathrm{g} / \mathrm{dL}$; plasma renin activity (PRA), $0.3 \mathrm{ng} / \mathrm{mL} / \mathrm{h}$; plasma aldosterone concentration (PAC), $145 \mathrm{pg} / \mathrm{mL}$; aldosterone / renin ratio (ARR), 483.3. Based on these findings, we thought it possible that this patient had concurrence of overt Cushing's syndrome and primary aldosteronism.

Table 1 Laboratory data in this subject

\begin{tabular}{|c|c|c|c|c|c|}
\hline \multicolumn{2}{|c|}{ Peripheral blood (reference range) } & \multicolumn{2}{|c|}{ Metabolism and endocrine markers } & \multicolumn{2}{|l|}{ Electrolytes } \\
\hline $\mathrm{RBC}$ & $455 \times 10^{4} / \mu \mathrm{L}(4.35-5.55)$ & Plasma glucose & 90 mg/dL (73-109) & Sodium & $144 \mathrm{mEq} / \mathrm{L}(138-145)$ \\
\hline Hemoglobin & $12.6 \mathrm{~g} / \mathrm{dL}(13.7-16.8)$ & $\mathrm{HbA} 1 \mathrm{c}$ & $6.2 \%(4.9-6.0)$ & Potassium & 3.9 mEq/L (3.6-4.8) \\
\hline WBC & $7350 / \mu \mathrm{L}(3300-8600)$ & LDL cholesterol & 147 mg/dL (65-139) & Chloride & $106 \mathrm{mEq} / \mathrm{L}(101-108)$ \\
\hline Neutrophils & $74.0 \%(52-80)$ & HDL cholesterol & 60 mg/dL (40-90) & Calcium & 9.3 mg/dL (8.8-10.0) \\
\hline Eosinophils & $1.1 \%(1-5)$ & Total cholesterol & 242 mg/dL (142-248) & Phosphorous & 4.6 mg/dL (2.7-4.6) \\
\hline Basophi & $0.4 \%(0-1)$ & Triglyceride & 150 mg/dL (40-149) & Magnesium & $2.1 \mathrm{mg} / \mathrm{dL}(1.9-2.6)$ \\
\hline Monocyte & $5.6 \%(1-6)$ & TSH & $0.96 \mu \mathrm{U} / \mathrm{mL}(0.4-6.0)$ & Urinary storage & \\
\hline Lymphocytes & $18.9 \%(20-40)$ & FT3 & $2.74 \mathrm{pg} / \mathrm{mL}(2.5-4.2)$ & Cortisol & $73.9 \mu \mathrm{g} /$ day \\
\hline Platelet & $25.4 \times 10^{4} / \mu \mathrm{L}(15.8-34.8)$ & FT4 & $1.20 / \mathrm{mL}(0.8-1.6)$ & Aldosterone & $7.5 \mu \mathrm{g} / \mathrm{day}$ \\
\hline \multicolumn{2}{|c|}{ Blood biochemistry } & $\mathrm{ACTH}$ & 1.7 pg/mL (7.2-63.3) & Adrenaline & 6.5 ㅆg/day \\
\hline Total protein & $7.0 \mathrm{~g} / \mathrm{dL}(6.6-8.1)$ & Cortisol & $10.8 \mu \mathrm{g} / \mathrm{dL}(4.5-21.1)$ & Noradrenaline & 105.7 mg/day \\
\hline Albumin & $4.2 \mathrm{~g} / \mathrm{dL}(4.1-5.1)$ & DHEA-S & 31 mg/dL (24-244) & Dopamine & 594.8 ㅆ/day \\
\hline Total bilirubin & 0.4 mg/dL (0.4-1.5) & $\mathrm{GH}$ & 0.10 ng/mL (0-2.47) & Metanephrine & 0.03 mg/day \\
\hline AST & 24 U/L (13-30) & IGF-1 & 86 ng/mL (72-221) & Normetanephrine & 0.14 mg/day \\
\hline ALT & 27 U/L (10-42) & PRA & $0.2 \mathrm{ng} / \mathrm{mL} / \mathrm{h}(0.2-2.3)$ & 5-HIAA & 2.9 mg/day \\
\hline Y-GTP & 19 U/L (13-64) & PAC & 64.8 pg/mL (30-159) & VMA & \\
\hline $\mathrm{LDH}$ & 234 U/L (124-222) & ARR & 324 & Concentration & 3.4 mg/day \\
\hline ALP & 265 U/L (106-322) & Adrenaline & 8 pg/mL (0-100) & Converted value & 3.5 mg/mg.Cre \\
\hline Creatinine & 0.65 mg/dL (0.65-1.07) & Noradrenaline & 2217 pg/mL (100-450) & HVA & \\
\hline BUN & 15 mg/dL (8-20) & Dopamine & $\leq 5 \mathrm{pg} / \mathrm{mL}(0-20)$ & Concentration & 2.9 mg/day \\
\hline Uric acid & 5.2 mg/dL (3.7-7.8) & & & Converted value & $3.4 \mathrm{mg} / \mathrm{mg}$. Cre \\
\hline
\end{tabular}

Abbreviations: $R B C$ red blood cells, WBC white blood cells, $A S T$ aspartate aminotransferase, $A L T$ alanine aminotransferase, $\gamma$-GTP $\gamma$-glutamyl transpeptidase, $L D H$ lactate dehydrogenase, $A L P$ alkaline phosphatase, $B U N$ blood urea nitrogen, $T S H$ thyroid-stimulating hormone, $F T 3$ free triiodothyronine, $F T 4$ free thyroxine, $A C T H$ adrenocorticotropic hormone, GH growth hormone, IGF-1 insulin-like growth hormone, PRA plasma renin activity, $P A C$ plasma aldosterone concentration, ARR aldosterone / renin ratio, 5-HIAA 5-hydroxyindole acetic acid, VMA vanillyl mandelic acid, HVA homovanillic acid 
To further examine such abnormalities in this subject, she was hospitalized in our department. On admission, her height, body weight and body mass index were $146.5 \mathrm{~cm}, 63.0 \mathrm{~kg}$ and $29.4 \mathrm{~kg} / \mathrm{m}^{2}$. Blood pressure, heart rate and body temperature were $150 / 84 \mathrm{mmHg}, 75 / \mathrm{min}$ and $36.1{ }^{\circ} \mathrm{C}$. Table 1 shows the data on admission. Endocrine markers were as follows: ACTH, $<1.7 \mathrm{pg} / \mathrm{mL}$; cortisol, $10.8 \mu \mathrm{g} / \mathrm{dL}$; PRA, $0.2 \mathrm{ng} / \mathrm{mL} / \mathrm{h}$; PAC, $64.8 \mathrm{pg} / \mathrm{mL}$; ARR, 324. There was no abnormality in glucose metabolism and electrolytes. Liver function and renal function were within normal range.

There was no daily variation in $\mathrm{ACTH}$ and cortisol levels (ACTH: $8 \mathrm{am}, 1.7 \mathrm{pg} / \mathrm{mL}, 2 \mathrm{pm},<0.2 \mathrm{pg} / \mathrm{mL}$, $8 \mathrm{pm}, 1.4 \mathrm{pg} / \mathrm{mL}, 11 \mathrm{pm}, 1.0 \mathrm{pg} / \mathrm{mL}$; cortisol: $8 \mathrm{am}$, $10.8 \mu \mathrm{g} / \mathrm{dL}, 2 \mathrm{pm}, 11.6 \mu \mathrm{g} / \mathrm{dL}, 8 \mathrm{pm}, 10.8 \mu \mathrm{g} / \mathrm{dL}, 11 \mathrm{pm}$, $10.0 \mu \mathrm{g} / \mathrm{dL}$ ). In dexamethasone suppression test, cortisol level was not reduced ( $1 \mathrm{mg}$ dexamethasone: $\mathrm{ACTH},<$ $1.0 \mathrm{pg} / \mathrm{mL}$; cortisol $13.2 \mu \mathrm{g} / \mathrm{mL} ; 8 \mathrm{mg}$ dexamethasone: ACTH, $<1.0 \mathrm{pg} / \mathrm{mL}$; cortisol $12.2 \mu \mathrm{g} / \mathrm{mL})$. In standing load test, PRA was not increased (PRA: from $0.2 \mathrm{ng} / \mathrm{mL} /$ $\mathrm{h}$ to $0.2 \mathrm{ng} / \mathrm{mL} / \mathrm{h}$; PAC: from $64.8 \mathrm{pg} / \mathrm{mL}$ to $81.9 \mathrm{pg} /$ $\mathrm{mL})$. In captopril tolerance test, PRA was not increased (PRA: from $<0.2 \mathrm{ng} / \mathrm{mL} / \mathrm{h}$ to $0.2 \mathrm{ng} / \mathrm{mL} / \mathrm{h}$; PAC: from $89.6 \mathrm{pg} / \mathrm{mL}$ to $41.0 \mathrm{pg} / \mathrm{mL}$ ). In abdominal computed tomography, tumorous lesion was observed in right adrenal gland $(25 \mathrm{~mm} \times 22 \mathrm{~mm}$ ) (Fig. 1A). In adosterol scintigraphy, high accumulation was observed in the right adrenal gland, whereas there was no accumulation in the left adrenal gland (Fig. 1B). It is well known that selective adrenal vein sampling is very important to distinguish unilateral hyperaldosteronism from bilateral one. In this subject, however, overt Cushing's signs such as moon face and central obesity were observed and the increase of aldosterone level was not drastic. Based on these findings, we thought that the main pathology in this subject was due to Cushing's syndrome rather than primary aldosteronism and thus we decided not to perform such sampling in this subject. We finally diagnosed this subject as overt Cushing's syndrome and primary aldosteronism. After then, laparoscopic right adrenalectomy was performed. We further investigated the characteristic of the adrenal tissue. First, in hematoxylin and eosin (HE) staining, nodular lesions with coat forming and clear boundaries were observed, and nodular lesion was occupied by foamy and clear cells. Nuclear atypica and abnormal mitosis were not observed, suggesting that there were no malignant findings (Fig. 2A, B). Second, in immunostaining for cytochrome P450 (CYP) 11B1, a cortisol-producing enzyme, diffuse staining was observed in tumorous lesion (Fig. 3A, B). Third, in immunostaining for CYP11B2, an aldosteroneproducing enzyme, CYP11B2 expression was not observed in tumorous lesion (Fig. 3C). Interestingly, however, strong CYP11B2 expression was observed in

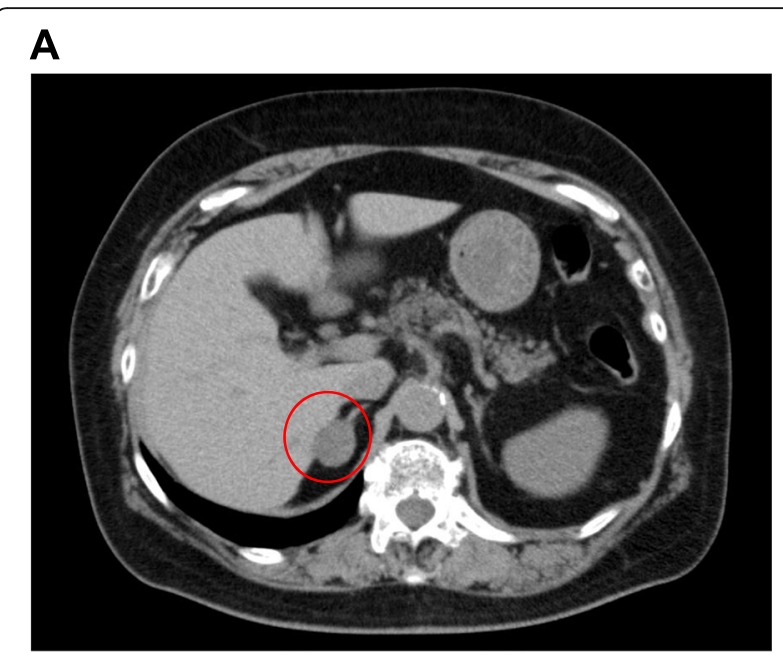

B

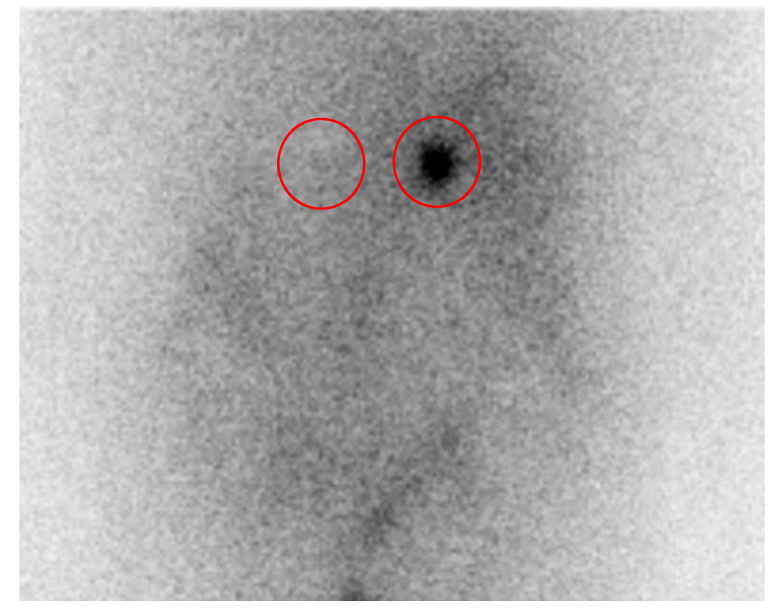

Fig. 1 A In abdominal computed tomography, tumorous lesion was observed in right adrenal gland. Its size was as large as $25 \mathrm{~mm} \times$ $22 \mathrm{~mm}$. B In adosterol scintigraphy, high accumulation was observed in the same area, whereas there was no accumulation at all in the other side

adjacent adrenal cortex, indicating the presence of aldosterone-producing cell cluster. After the operation, cortisol level was markedly decreased to $0.6 \mu \mathrm{g} / \mathrm{dL}$, and moon face and central obesity were drastically recovered around 5 months after the operation. In contrast, aldosterone level was not reduced even after the right adrenalectomy. These data suggest that the left as well as right adrenal gland secreted aldosterone although cortisol was secreted only from the right adrenal gland.

\section{Discussion and conclusions}

In this case report, we showed a subject who had overt Cushing's syndrome and primary aldosteronism at the same time. Furthermore, in pathological analysis, both cortisol-producing tumor and aldosteroneproducing cell cluster in adjacent adrenal cortex, but 

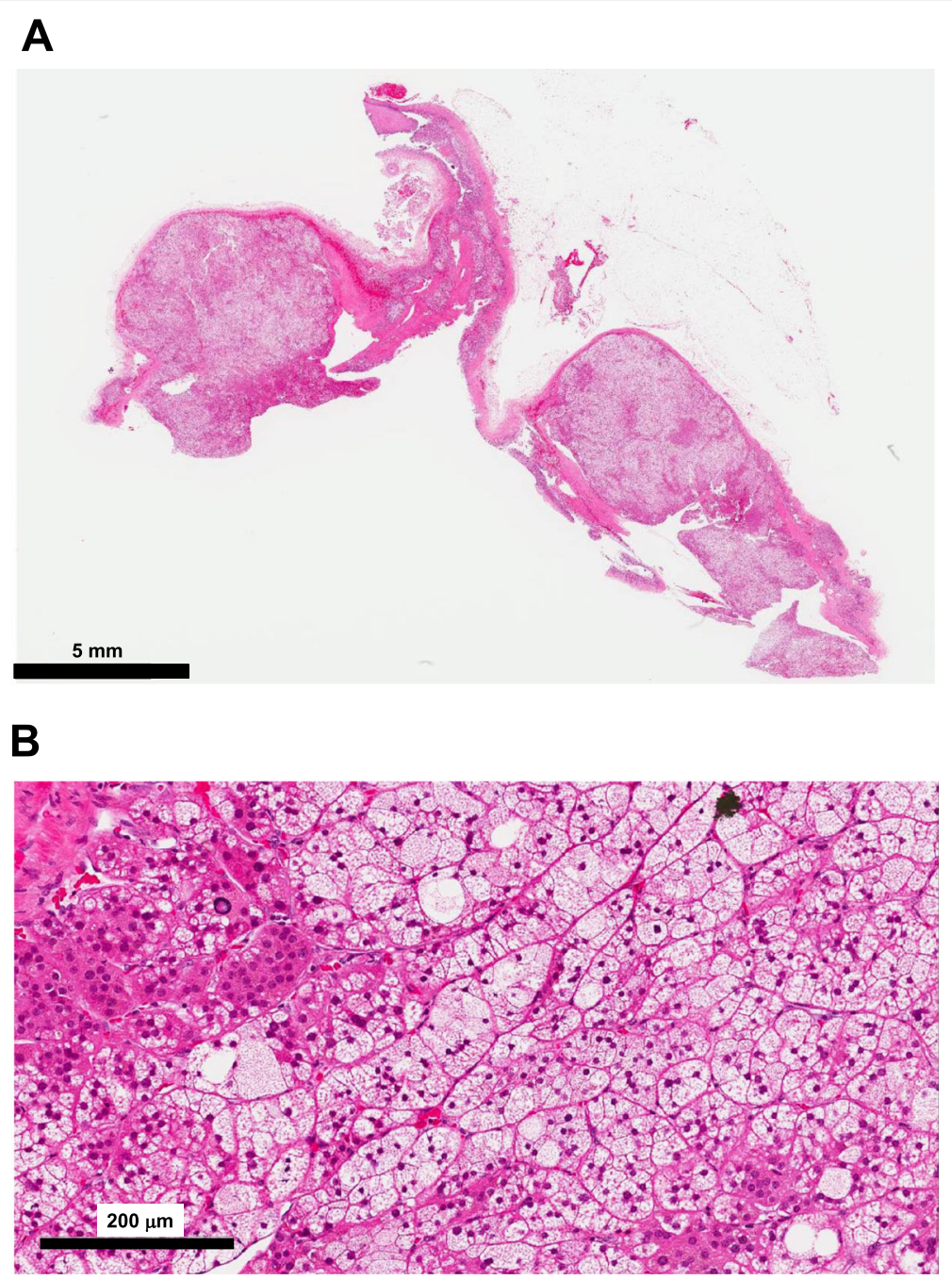

Fig. 2 A In hematoxylin and eosin (HE) staining, nodular lesions with coat forming and clear boundaries were observed. B In high-power field in HE staining, nodular lesion was occupied by foamy and clear cells. Nuclear atypica and abnormal mitosis were not observed, which suggested that there were no malignant findings

not in tumorous lesion, were clearly detected at the same time in this subject. To the best of our knowledge, this is the first report about concurrence of overt Cushing's syndrome and primary aldosteronism accompanied by the presence of aldosteroneproducing cell cluster in adjacent adrenal cortex. In addion, previously it was thought that both aldosterone and cortisol were produced in aldosteroneproducing adenoma [2-4], but new concept has emerged that cause of primary aldosteronism is related to the presence of aldosterone-producing cell cluster in adjacent adrenal cortex $[5,6]$. We think that this case report strongly strengthened abovementioned relatively new concept about the cause of primary aldosteronism.

In addition, adrenal venous sampling is generally recommended, and indeed it is often used for local diagnosis of primary aldosteronism in clinical practice [11]. It has been reported, however, that when tumor diameter is relatively large and accumulation is obviously unilateral in adosterol scintigraphy, adrenal venous sampling is not necessarily performed [12]. In this subject, adrenal tumor size was as large as $25 \mathrm{~mm} \times 22 \mathrm{~mm}$ and accumulation was obviously unilateral in adosterol scintigraphy. In addition, this subject had overt Cushing's syndrome together with moon face and central obesity and strongly hoped for undergoing surgery. Based on these circumstances, we prioritized performance of surgery rather than adrenal venous sampling in this subject.

Taken together, we should bear in mind the possibility that concurrence of overt Cushing's syndrome and primary aldosteronism is accompanied by aldosteroneproducing cell cluster in adjacent adrenal cortex. 


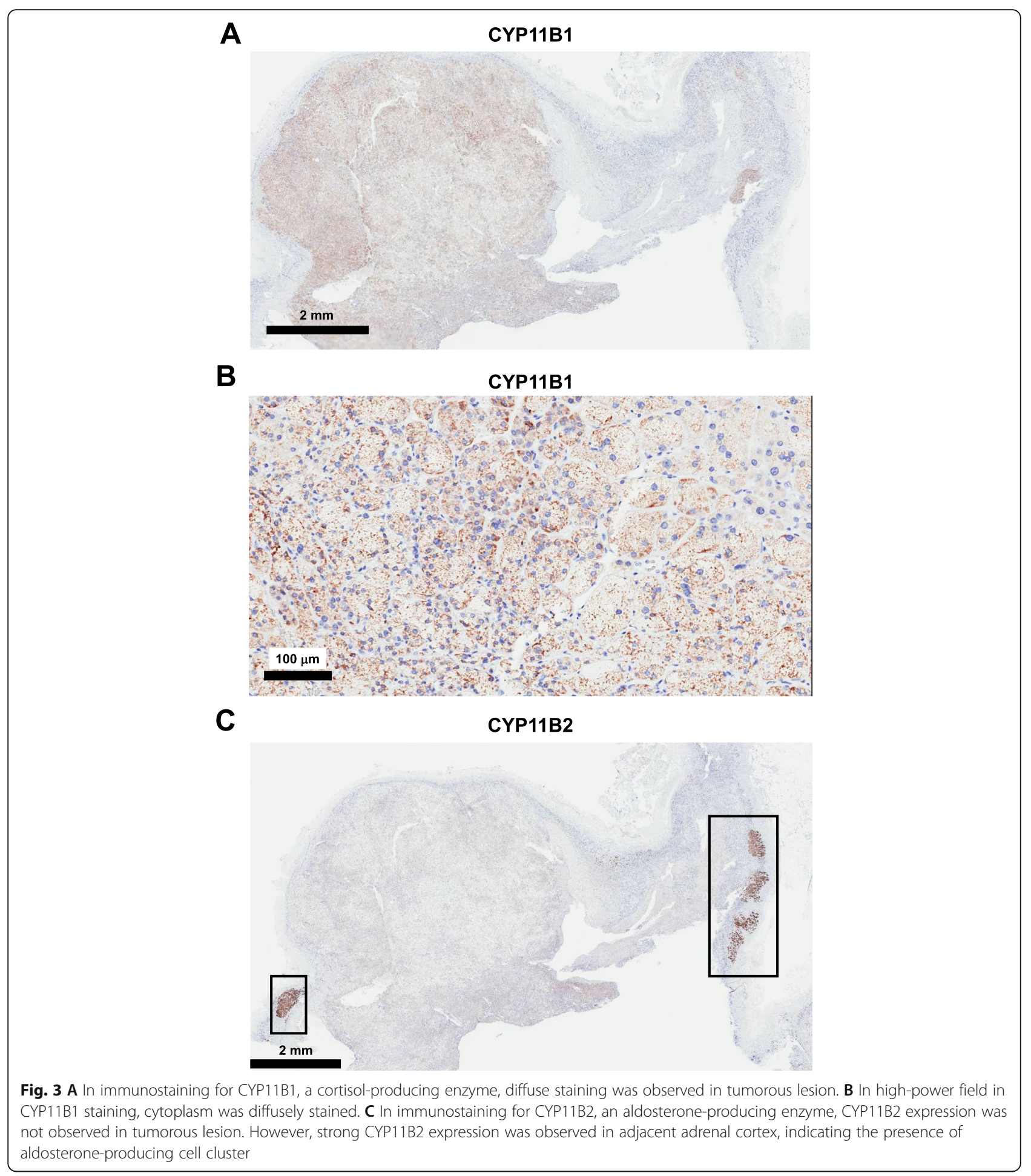




\section{Abbreviations}

CYP: Cytochrome P450; ACTH: Adrenocorticotropic hormone; PRA: Plasma renin activity; PAC: Plasma aldosterone concentration; ARR: Aldosterone / renin ratio

\section{Acknowledgements}

Not applicable

\section{Authors' contributions}

Y.F. F.T., T.M., H.K. researched data and/or wrote the manuscript. J.S, M.S., S.K. S.N., K.K. contributed to discussion. All authors have read and approved the manuscript.

\section{Funding}

The authors declare that there is no funding associated with this manuscript.

\section{Availability of data and materials}

Not applicable.

\section{Declarations}

\section{Ethics approval and consent to participate}

Not applicable.

\section{Consent for publication}

Written informed consent was obtained from the patient for publication of this Case report and any accompanying images. A copy of the written consent is available for review by the Editor of this journal.

\section{Competing interests}

We do not have any potential conflicts of interest relevant to this article.

Received: 25 March 2021 Accepted: 18 July 2021

Published online: 12 August 2021

\section{References}

1. Savard E, Amar L, Plouin PF, Steichen O. Cardiovascular complications associated with primary aldosteronism: a controlled cross-sectional study. Hypertension. 2013;62:331-6.

2. Honda T, Nakamura T, Saito Y, Ohyama Y, Sumino H, Kurabayashi M. Combined primary aldosteronism and preclinical Cushing's syndrome: an unusual case presentation of adrenal adenoma. Hypertens Res. 2001;24:723-36

3. Adachi J, Hirai Y, Terui K, Nakao T, Fukuda Y, Suda T, Sasano H. A report of 7 cases of adrenal tumors secreting both cortisol and aldosterone. Intern Med. 2003;42:714-8.

4. Fujii H, Kamide K, Miyake O, Abe T, Nagai M, Nakahama H, Horio T, Takiuchi S, Okuyama A, Yutani C, Kawano Y. Primary aldosteronism combined with preclinical Cushing's syndrome in an elderly patient. Circ J. 2005;69(1425):1427.

5. Gomez-Sanchez CE, Gomez-Sanchez EP. Immunohistochemistry of the adrenal in primary aldosteronism. Curr Opin Endocrinol Diabetes Obes. 2016;23:242-8

6. Nishimoto K, Seki T, Hayashi Y, Mikami S, Al-Eyd G, Nakagawa K, Morita S, Kosaka T, Oya M, Mitani F, Suematsu M, Kabe Y, Mukai K. Human adrenocortical remodeling leading to aldosterone-producing cell cluster generation. Int J Endocrinol. 2016:2016:7834356. https://doi.org/10.1210/jc.2015-3285.

7. Nishimoto K, Seki T, Kurihara I, Yokota K, Omura M, Nishikawa T, Shibata H, Kosaka T, Oya M, Suematsu M, Mukai K. Case report: nodule development from subcapsular aldosterone-producing cell clusters causes hyperaldosteronism. J Clin Endocrinol Metab. 2016;101:6-9.

8. Omata K, Tomlins SA, Rainey WE. Aldosterone-producing cell clusters in normal and pathological states. Horm Metab Res. 2017:49:951-6.

9. Lim JS, Rainey WE. The potential role of aldosterone-producing cell clusters in adrenal disease. Horm Metab Res. 2020;52:427-34.

10. Sun N, Meyer LS, Feuchtinger A, Kunzke T, Knösel T, Reincke M, Walch A Williams TA. Mass spectrometry imaging establishes 2 distinct metabolic phenotypes of aldosterone-producing cell cClusters in primary aldosteronism. Hypertension. 2020;75:634-44.

11. Lim V, Guo Q, Grant CS, Thompson GB, Richards ML, Farley DR, Yong WF Jr. Accuracy of adrenal imaging and adrenal venous sampling in predicting surgical cure of primary aldosteronism. J Clin Endocrinol Metab. 2014:99: 2712-9
12. Rossi GP, Auchus RJ, Brown M, Lenders JWM, Naruse M, Plouin PF, Satoh F, Yong WF Jr. An expert consensus statement on use of adrenal vein sampling for the subtyping of primary aldosteronism. Hypertension. 2014; 63:151-60.

\section{Publisher's Note}

Springer Nature remains neutral with regard to jurisdictional claims in published maps and institutional affiliations.
Ready to submit your research? Choose BMC and benefit from:

- fast, convenient online submission

- thorough peer review by experienced researchers in your field

- rapid publication on acceptance

- support for research data, including large and complex data types

- gold Open Access which fosters wider collaboration and increased citations

- maximum visibility for your research: over $100 \mathrm{M}$ website views per year

At $\mathrm{BMC}$, research is always in progress.

Learn more biomedcentral.com/submissions 